\title{
Integration of Forest and Climate Change Policies in Nepal
}

\author{
Ganesh Paudel $^{*}$, Shankar Adhikari ${ }^{1}$, Prabin Bhusal ${ }^{2}$ \\ ${ }^{1}$ Ministry of Forests and Environment, Nepal \\ ${ }^{2}$ Institute of Forestry, Tribhuvan University, Pokhara, Nepal \\ ${ }^{*}$ Corresponding author: ecopaudel@gmail.com
}

\section{Abstract}

Climate change poses threats to forest ecosystems, forest dependent communities and society as a whole. Incorporation of climate change in forest policy and vice-versa is essential to effectively deal with climate change impacts while managing forest. Review of climate change and forest policies, incorporating forestry and climate change issues has not been substantially discussed and analyzed yet in Nepal. In this paper we aim to review the climate change and forest policies in terms of its content, relevancy and adequacy. We reviewed five forest policies and three climate change related plans and policies regarding integration of forest and climate change issues in respective policies. Our review reveals that forest policies contain notable provisions in regard to the contribution of forestry to climate change mitigation and adaptation. However, new and emerging issues such as climate refugia and invasive species are least concerned in forest policies. Climate change policies also contain provisions for forest management focusing on the mobilization of forest user groups for carrying out adaptation activities at the local level. However, the implementation of both polices seems poor due to lack of legal framework. Therefore, formulation of legal framework for implementation of these policies is essential. Similarly, we suggest both policies need to be revised incorporating the provisions based on scientific findings and field experience.

Key words: Adaptation, climate change, forest management, mitigation, policy

\section{INTRODUCTION}

Climate change is a real phenomenon (Adger et al., 2005). Global temperature has increased by $0.85[0.65 \text { to } 1.06]^{\circ} \mathrm{C}$ over the period from 1880 to 2012 (IPCC, 2013). This change in climate has adverse impact on the earth's ecological (Mccarty, 2001; Parmesan and Yohe, 2003) and socioeconomic processes (Stern, 2007). Impacts of climate change are evident worldwide (Walther et al., 2002).

Climate change has impacted various sectors including the forest and biodiversity (GoN, 2010). Climate change poses a direct threat to forest ecosystems, forest dependent communities and society as a whole through reduction of forest ecosystem goods and services (Streck and Scholz, 2006; Braatz et al., 2011). Forests are expected to face increased incidence of fire, pests and pathogens, invasive species, landslides and other disturbances (Dale et al., 2001). Similarly, changes in climate will also affect tree physiology and phenology, forest growth and biodiversity, with impacts on forest-dependent people and wider society (RECOFTC, 2012). Climate change has induced upward shifting of vegetation, which causes the loss of valuable medicinal plants of alpine region (Joshi et al., 2015). It has directly reduced the availability of forest resources 
for the forest dependent communities and indirectly impacted tourism sector reducing the flow of tourists (Shrestha and Shrestha, 2012) especially in the ecotourism. Loss of diversified income sources viz. tourism and the increased pressure on land and forest resources are likely to have further implications for conflicts over resource access and control (Obioha, 2008; HomerDixon, 1994).

Afforestation, sustainable forest management (SFM) and reducing the rate of deforestation are the most cost-effective mitigation options in forestry (IPCC, 2014). Anthropogenic forest degradation and biomass burning including forest fires contribute to GHG emission and hence leveraging the mitigation potential in the sector is extremely important in meeting emission reduction targets (Smith et al., 2014). Forest is the most effective way for carbon sequestration and storage, as it absorbs carbon worth hundreds of billions of dollars if an equivalent sink had to be created in other ways (Canadell and Raupach, 2008). Therefore, forests add to the problem of climate change but it can also be a tool in mitigating climate change as photosynthesis binds $\mathrm{Co}_{2}$ and stores it as carbon in plants and when forests are cleared, they release carbon and act as a source of GHG emissions (Streck and Scholz, 2006). Forests also play a vital role in moderating the adverse impacts of climate change (Spittlehouse and Steward, 2003) serving both mitigation and adaptation means to climate change. Forests contain a significant portion of world's terrestrial biodiversity. They play a role in protecting watersheds that are critical for the supply of clean water. Similarly, the forest supports the community to increase its adaptive capacity. Forests help the society strengthen resilience to climate change, and support livelihood strategies (RECOFTC, 2012). Different forest management activities are helpful to combat adverse impacts of climate change (CPF, 2008; FAO, 2010).

Climate change is regarded as one of the crosscutting issues, which does not just span across distinct land uses (Pramova et al., 2015) and hence it needs to be integrated into respective policies by different sectors. Understanding the benefits of forests regarding climate change leads to the formulation of forestry and land-use policies to deal with the impacts of climate change. Thus formulated policies must recognize the multitude of forest influences, their relative effects on climate change, and their long-term effectiveness and sustainability in a changing climate (Boson, 2008). On the other hand, it is equally important to evaluate and incorporate the long term impacts of climate change on forests and analyze and determine the future policies and actions to respond to that threat (Spittlehouse and Steward, 2003). Similarly, along with other factors (e.g., ecosystem richness, ecosystem health, etc.) existing policies and response mechanism are used to determine the adaptive capacity of forest and biodiversity sector (MoPE, 2017b).

The policies in Nepal lack two-way linkage of the forest and climate science. In this context, the analysis of forestry sector policies with integration of climate change issues and vice versa is necessary to improve both forest and climate change policies and its impact. Similarly, the 
policy making process in Nepal provides very little space for public debate (Ojha et. al., 2007) and these are not informed by or consistent with the local adaptive initiatives. Therefore, in this paper we have reviewed the related forest and climate change policies from the perspective of addressing climate change agenda in forest policies and vice-versa particularly with regards to the policy content and its relevancy in changing context.

\section{Methodology}

We reviewed recently endorsed/revised forest policies considering whether these policies envision the provisions on climate change. For this, five forestry policies viz. Forest policy, 2015, Forest Act, 1993, Forestry Sector Strategy (20162025), Nepal Biodiversity Strategy and Action Plan (2014-2020) and Community Forestry Development Guideline (Third Revision, 2014) were reviewed separately. Similarly we also reviewed three climate change policies of Nepal viz. NAPA, 2010, Climate Change Policy, 2011 and National Framework for Local Adaptation Plan of Action, 2011. The primary focus of our review was on the content and relevancy of these policies regarding their effects on forest and climate change phenomenon and how they have put the relationships of climate change and forestry in addressing their two way impacts. Further, informal discussions and series of meetings were held with the officials of then Ministry of Forests and Soil Conservation (MoFSC) and Ministry of Population and Environment (MoPE) which now merged in Ministry of Forests and Environment (MoFE). We also tried to analyze the features and inadequacies of these policies in integrating the climate change and forestry issues.

\section{Discussion}

\section{Climate Change Issues in Existing Forest Policies and Guidelines}

\section{Forest Policy, 2015}

Forest policy was formulated with a long term vision of contributing to local and national prosperity through sustainable management of forest, biodiversity and watershed. Adaptation to and mitigation of adverse impacts of climate change is one among the seven major themes of this policy. Climate friendly land use and forest management and increasing access to financial resources and technical knowledge along with capacity building to reduce the impacts of climate induced hazards were other strategies which are incorporated in the policy. This policy has 12 working policies (see Box 2) for the effective implementation regarding climate change issues. Notable working policies include integrating forest and watershed management with food security and climate induced hazards, increasing carbon stock, promoting local technologies, increasing participation, research, and use of alternative technologies.

Forest policy was finalized after a rigorous discussion at the centre and field level, considering the local need and resilient capacity.

Hence it has some notable provisions regarding climate change. It emphasizes both the adaptation and mitigation through community based forest management. It aims to implement Reducing Emission form Deforestation and Forest Degradation (REDD+) program to enhance carbon stock in the forests. Technology development, transfer and utilization to mitigate the 
adverse impacts and conducting studies on the impact of climate change on ecosystem are highlighted. However effective implementation is lacking for these policies. This policy has some shortcomings which need to be addressed. No one size fits all; different forest types have different potentialities and need specific treatment, which is not recognized and addressed by the policy. Priority is given to forest fire management; however, other impacts of climate change such as invasive species and pest control are not well identified, which is critical while dealing with the adverse climatic conditions and forest management. Similarly, the policy does not incorporate the policies and programs on climate refugia management. The recognition of existing adaptation measures adopted by the local community and enhancing them with appropriate technology for its sustainable use and its institutionalization is another important aspect which is missing in the policy.

\section{Box 1 : Working policies on Climate Change in Forest Policy, 2015 (unofficial translation)}

- Alignment of climate change adaptation with the forest and watershed management, food security and water induced disaster control.

- Community based forest and watershed management will be made climate friendly employing adaptation based on local knowledge, skills and technology and mitigating adverse impacts of climate change.

- Enhancement of carbon stock through sustainable management of forests. Providing subsidy for activities which reduces carbon emission while using forest and forest products.

- Investment of certain portion of revenue generated from forest product in forest fire control and other forest conservation activities to promote carbon sequestration.Identification, development and utilization of appropriate technology to mitigate adverse impacts of climate change. Forest management plan will be made climate change adaptation friendly.

- Regular studies, research and monitoring of existing and potential impacts and risk of climate change to ecosystem will be carried out.

- Forest fire control employing preventive and rehabilitative measures through people's participation and use of modern technology.

- Formulation and implementation of policies and programs in accordance with REDD+ to generate more resources through international mechanisms and world carbon trade.

- Identification of vulnerable zones and communities and implementation of programs to reduce climate change vulnerability in these areas.

- Technical and financial assistance will be provided to the users of alternative energy, biogas, bio-briquette, improved cooking stoves, biofuel, etc

(Source: GoN, 2015)

\section{Forest Act, 1993}

Forest act is one of the major legislative instruments for governing the forest resources of Nepal. It was promulgated in 1993 and till date two amendments have been made to address the contemporary foresty issues in changing context. Climate change as such has not been explicitly mentioned in the act. However, on the second amendment in 2016 the concept of environmental services and carbon storage was identified as one of the environmental services and has been incorporated in the act.

The section 67 (B) of the act has emphasized the "management, utilization and benefit sharing of the environmental services obtained from forest". Now, the forest administration is working to bring new federal forest act to incorporate provisions envisioned in the constitution and unbundling report. The new federal forest act should clarify the provisions of these environmental services from the forest 
and should identify the possible solution for adaptation to the impact of climate change.

\section{Forestry Sector Strategy, (2016-2025)}

Nepal prepared the Forestry Sector Strategy (FSS) in 2016 with the vision of sustainable management of forest ecosystems and optimization of biodiversity and watersheds for national prosperity (GoN, 2016). One of the goals of the FSS was to make resources such as forest, biodiversity, plant resources, wildlife, watersheds and other ecosystem climate resilient. There are five expected outcomes to achieve through the goal stated in the FSS. One of them is "climate resilient capacity of society and forest ecosystems enhanced". To achieve this outcome, several activities have been envisioned (box 2). FSS set the target on forestry sector to achieve by the 2025. Targets related to climate change are (i) enhancement of carbon stock in Nepal's forest by at least 5\%, (ii) reducing mean annual deforestation rate to $0.05 \%$ (iii) operating forest carbon trade/payment mechanism (iv) protecting at least 200,000 ha areas through implementation of adaptation plan and (v) mainstreaming community/Ecosystem-based adaptation approach.

Climate change mitigation and resilience is one of the strategic pillars of the FSS. To achieve the goals seven key thematic areas are identified by FSS of which responding to climate change is one. Priority actions are identified for both adaptation and mitigation. Seven actions are identified under the adaptation and eleven actions are identified under mitigation.

FSS has more practical targets to be achieved by 2025 , which shows that FSS tries to translate policies into operational targets. It recognizes site-based actions and locally applicable technologies to manage forest fires. Priority actions are identified under both adaptation and mitigation headings to give message that both are equally important for us. Role of local forest user group in climate change adaptation is recognized. FSS identifies the site specific actions for different physiographic regions viz. Terai, Chure, Midhills and High Mountain.

However, there are some shortcomings of the FSS as well with respect to climate change. As in forest policy, it has also failed to identify programs for managing the climate refugia. Landscape level management, especially north south corridor, helps to manage climate refugia, which is missing in the strategy. There could be several co-benefits of mitigation actions through forest management, but FSS is silent on this aspect.

Box 2: Activities for achieving outcome of FSS on climate change

- Support the adaptive capacity of local communities and forest ecosystems;

- Promote ecosystem-based and communitybased resilience measures;

- Establish forest carbon trade or payment mechanisms by linking forests, biodiversity and watershed conservation and management;

- Develop and strengthen mechanisms for payment for ecosystem services (PES); and

- Promote biomass-based renewable energy

(Source: GoN, 2016a) 
Nepal Biodiversity Strategy and Action Plan (NBSAP) (2014-2020)

Nepal is a party to the convention on biological diversity (CBD) since 1992. NBSAP has been formulated by Nepal to conserve and sustainably manage the biodiversity resources of the country. Adaptation to and mitigation of the adverse impacts of climate change is one of the cross sectoral theme of the NBSAP. Two identified strategies under this theme are (i) adaptation to and mitigation of the impacts of climate change on biodiversity and (ii) enhancing the resilience of ecosystems, species and human communities to the climate change impacts.

Priority actions envisioned for adaptation and mitigation are long term environmental monitoring, low carbon economic development strategy formulation and revision or development of guidelines for integration of biodiversity on climate change. Similarly, the adaptation programs, climatic change vulnerability assessment of ecosystems and species, promotion of environment-friendly farming systems and implementation of payment for ecosystem services (PES) and REDD+ are also identified. Priority actions for enhancing resilience of ecosystems, species and communities are integrated climate risk/ vulnerability approach in biodiversity management. Further, the emphasis has been given to improving connectivity of natural ecosystems particularly northsouth connectivity and development and implementation of climate change adaptation plans by forest user groups at local level.
NBSAP has many good provisions in regard to the climate change. In addition to adaptation and mitigation it emphasizes the climate resilience. Long term environmental monitoring is proposed to identify the adverse impacts of climate change on overall environment. It emphasizes the operationalization of PES. Improving connectivity of natural ecosystems is envisioned which is useful in managing the climate refugia. However, NBSAP as an action plan has failed to come up with the time limit to carry out different activities. Though it has highlighted the REDD+ activities as a major mitigation strategy, it hasn't acknowledged the alternative technologies to reduce emissions.

\section{Community Forestry Development}

Guideline (Third Revision, 2014)

Community forestry development guideline has been prepared to facilitate the process of community forestry in different aspects including preparation of Community Forests User Groups (CFUGs) constitution and operational plan. In third amendment of this guideline the provisions on climate change adaptation has been included. It has briefly illustrated the importance of climate change adaptation activities in community forestry. CFUGs can prepare the community adaptation plans. It can be considered as the part of operational plan after approval from the District Forest Office. Community forests are recognized as successful program in managing forest (Paudel, 2014; Paudel, 2015) and are now involved in preparing and implementing climate change adaptation plans as well. Adaptation plans have been prepared covering the adaption activities identified 
in the NAPA's six thematic areas viz. agriculture and food security, forest and biodiversity, climate induced disasters, water resources and energy, physical infrastructure and urban settlements and human health.

The guideline has eased the CFUGs for developing local adaptation plans putting forest as one of the major contributing factors in communities' adaptation activities. On the other hand communities can do forest management activities considering the impact of climate change on forest and its resources. This has been accelerating the preparation of adaptation plans at community level although implementation aspect is weak. The budget deficit has hindered the implementation of activities envisioned in adaptation plan (Acharya and Paudel, 2016). Similarly the guideline is not clear on key priority activities-- on how, why and what the community should put emphasis so that the intended activities could be carried out.

\section{Forestry issues in Climate Change Related Plans \& Policies}

\section{National Adaptation Programme of Action, 2010}

Nepal formulated the National Adaptation Programme of Action (NAPA) with the aim of addressing urgent and immediate adaptation needs. During NAPA preparation six thematic areas were identified. Among them forest and biodiversity has been put with the aim of identifying the immediate adaptation actions. In NAPA, adaptation activities were identified and put into nine combined profiles project. Priority adaptation projects were also identified for the forest and biodiversity sector to be implemented immediately. It emphasizes the mobilization of community based user groups to plan and implement community based climate change adaptation activities. It believes CFUGs as the strongest and most influential community associations in the VDCs (Regmi and Karki, 2010) and recognizes its role in local level adaptation initiatives. Similarly it recognizes the importance of forest and ecosystem in reducing climate vulnerability.

Yet, the effective results of adaptation initiatives at community level and even at national level institutions have not been seen. The Ecosystem Based Adaptation (EbA) project was carried out in the Panchase region as a pilot project at the local level.

NAPA was focused on short term adaptation needs and long-term adaptation needs were not identified. Therefore, in order to complement the long term adaptation need as identified by the NAPA, National Adaptation Plan (NAP) process has already been initiated by the Ministry of Forests and Environment. Forest and biodiversity is also considered as the one thematic program of the NAP (MoPE, 2017a).

\section{Climate Change Policy 2011}

Climate change policy 2011 has been formulated with the vision of reducing adverse impacts of climate change and increasing resilience to contribute to the sustainable development of the country. Climate Change policy stated one of the objectives of the policy as,

"To enhance the climate adaptation and resilience capacity of local communities for optimum utilization of natural resources and their efficient management" (GoN, 2011). 


\section{Box 3 : Provisions under climate friendly} natural resources management

- Developing and implementing a scientific land use system;

- Proper utilization, promotion, conservation of forest resources as a means of alternative livelihoods;

- Prioritizingandimplementing programmes on the sustainable management of forests, agro-forestry, pasture, rangeland, and soil conservation that can address the impacts of climate change;

- Encouraging investments in clean energy sources with priority on hydropower from national, regional, and international sources.

- Conserving soil and water through measures such as source protection, rain water harvesting, and environmental sanitation;

- Encouraging carbon sequestration and investing some of the benefits from the use of forest products for controlling forest fires and conserving forests;

- Developing a mechanism for optimal utilization of international, regional and local funding sources, including reducing emissions from deforestation and forest degradation (REDD);

- Adopting a basin approach for water management through regular monitoring of water resource availability.

(Source : GoN, 2011)

Eight actions (Box 3) are identified to implement the policy provision on climate friendly natural resource management. These all sub-policies are directly or indirectly related with the forest management and incorporate the need of forest to reduce and manage climate change impacts. Climate Change policy emphasizes the sustainable management of forest resources and highlights the need of Reducing Emission from Deforestation and Forest Degradation (REDD+) both for better forest and livelihood benefits. Nepal approved the national REDD+ strategy in 2018 (GoN, 2018). Carbon measurement guideline was also formulated in 2011 to guide the carbon measurement in the different forest management regimes as envisioned by this policy. Policy encourages carbon sequestration by increasing investment in forest conservation. This policy tries to seek options for alternative livelihood to reduce pressure on forest resources; however, it has put its emphasis on carbon emission.

Climate change adaptations through forest management activities have vital roles and possibilities. However, this policy focuses more on mitigation aspects. It does not mention explicitly about the role of community forest user group in adaptation. This has prioritized the sustainable forestry but remained silent on identifying the main vehicle of sustainable forestry (HELVETAS and RRI, 2011). Similarly, this policy has no provision on assessment of ecological vulnerability and management of climate refugia. Climate change is responsible for the increasing threat of invasive species which this policy does not recognize.

Despite having the provision of spending at least $80 \%$ of total climate change budget at the local level, its implementation is poor. Financing to the climate change adaptation through community forest could have been improved if this provision is strictly implemented. This policy lacks a concrete plan of action and does not have supportive legislation and institutions to implement it (HELVETAS and RRI, 2011). 
It is also criticized that climate change policies in Nepal are prepared just for fulfilling international obligation rather than reflecting the local needs (Ojha et al., 2015). It needs to be revised to include the recent findings on climate change into policy as the knowledge in climate science is rapidly growing. New findings and data should be incorporated into data base and acted accordingly which makes policy more effective and helps in reducing vulnerability.

\section{National Framework on Local Adaptation Plan for Action, 2011}

It sets out the procedure for preparing and implementing local adaptation plan of actions. Seven steps (Box 4) were identified to be followed for the preparation and implementation of the adaptation plans. It also clarifies the process and tools of vulnerability assessment and identification of adaptation actions. This guideline is also helpful for the preparation and implementation of adaptation plans of the community forest user groups. This does not explicitly mention about forest but assessing ecosystem vulnerability and identifying adaptation activities in forest and biodiversity gives the notion of integration of forest for climate change adaptation.

Box 4 : Steps of LAPA Preparation and Implementation

- Climate change sensitisation

- Climate vulnerability and adaptation assessment

- Prioritisation of adaptation options

- LAPA formulation

- LAPA integration into planning processes

- LAPA implementation

- LAPA progress assessment

(Source: GoN, 2011)

\section{Integrating Policy Provisions}

We analyzed five forest policies and three climate changes polices with regard to what and how forestry and climate change policies incorporate forest and climate change issues in each policies. The analysis shows that forest policies to some extent have incorporated climate change issues and agendas in changing contexts; however, they are inadequate to accommodate new and emerging issues like climate refugia, mitigation co-benefits and ecosystem based adaptation and disaster risk reduction. Forest and biodiversity sector could have particular adaptation and mitigation options/strategies. These strategies could be helpful in enhancing the adaptive capacity which is missing in policies (MoPE, 2017a). Regarding mitigation, community forests are found sequestering carbon (Tripathi et al., 2017), which needs to be accelerated through incorporating carbon in community forest operational plans. The research on the ecosystem vulnerability and role of ecosystem in reducing climate change vulnerability needs to be carried out but this is less focused in climate and forest policies of Nepal. Similarly the study on impact of extreme climatic conditions to different type and condition of forest is needed (MoPE, 2017a) which should be highlighted through explicit policy provisions. Policies governing forest conservation and management are more effective when it involves both mitigation and adaptation aspects as these practices give various co-benefits in environmental and socio-economic terms (IPCC, 2014a). Forest policies need to integrate the climate change mitigation and adaptation aspects as part of forest management. 
Current forest management policies are based on how forests developed under past climatic conditions (Spittlehouse and Steward, 2003) but the climate is changing. Policy-makers and forest managers must accept the fact that climate change is real and forests and forest communities will have to face significant impacts (Spittlehouse and Steward, 2003). Thuy et al (2015), using the Indonesia and Vietnam as case studies, identified challenges at the national level but opportunities at the local level for integrating climate change adaptation and mitigation in climate change and forest policies. In Nepal's case, this has been very poorly acknowledged. Similarly the integration and coordination of forestry and climate change institutions from national to local level is crucial for the effective implementation of both policies. However, it is very weak and different institutions have overlapping claim on the same resources.

Problem is also associated with the climate change policies in terms of institutions. As a key institution to implement climate change policies in the past MoPE has not its own its institutional arrangement at the local level (HELVETAS and RRI, 2011) but now the situation is changed then MoFE is able to facilate adaptation activities at the local level. The CFUGs are the appropriate institutions for carrying out adaptation activities at local level (Khatri et al., 2013; Regmi and Karki, 2010) which is also indicated by the policy documents viz. NAPA (2010) and climate change policy (2011). Efforts are being made to develop guidelines for local level adaptation planning in forestry sector (eg, MSFP, 2015) and to develop coordination among the institutions but it still seems that these institutions are working on their own for same goal.

On the other hand, the weak implementation of adaptation plans is also due to lack of strong financial base (Acharya and Paudel, 2016). Maximum utilization of local resources and weak enterprise in forest and natural resource management has been the major cause of poor financial status of the local institutions. Similarly, the international lobbying for the securing climate funds is also weak. This condition can be improved if we formulate forestry and climate change policies with strong orientation on securing climate fund through effective implementation of climate change policy. Climate polices need to be revised when new lessons are learned (Ojha et al., 2015). And policy formulation should put the issues and lessons of local level at priority rather than more expert enquiry and dominated by international issues and agendas. Legislative provision on formulating and implementing community adaptation plans can be framed to enhance the formulation and effective implementation of community adaptation plans through CFUGs. While formulating the forest and climate change policies, the potentiality of forest management to combat climate change should be taken into consideration.

\section{Conclusion}

Forest policies prepared recently are gradually improving in terms of integrating the concept and issues of climate change. Likewise, climate change related plans and polices have tried to incorporate forest management activities for dealing with climate change impacts recognizing 
its role in adaptation and mitigation for benefitting local and global community. However, it needs improvement in several aspects including specific role of forests in mitigation and adaptation which should be identified and planned for actions in both forestry and climate change policies. Emphasis was given to increase the resilience capacity of community through community based adaptation and mitigation. Policies lack specific steps for dealing with the climate change from the forest management perspective. Ecosystem based climate change adaptation and resilience

\section{References}

Acharya, R. and Paudel, G. 2016. Implementation Status of Community Adaptation Plans: A Case Study from Parbat District, Nepal. International Journal of Environment, 5(3): 119-126.

Adger, W.N., Arnell, N.W. and Tompkins, E.L. 2005. Successful Adaptation to Climate Change Across Scales. Global Environmental Change, 15(2): 77-86.

Bista, R. and Gurung, N. 2013. Climate Change Adaptation and Local Institutions: How to Connect Community Groups with Local Government for Adaptation Planning. Journal of Forest and Livelihood, 11(1): 14-28.

Braatz, S., Rametsteiner, E. and Thunberg, J. 2011. Climate Change for Forest Policy-Makers, An Approach for Integrating Climate Change in Forest Programmes in Support of Sustainable Forest Management. Food and Agriculture Organization of the United Nations, Rome, Italy.

Canadell, J.G. and Raupach, M.R. 2008. Managing Forests for Climate Change Mitigation. Science, 320(5882): 1456-1457. has been less emphasized. Similarly, polices fail to identify the institutions and procedures for implementation and in most cases legislations have not been shaped to implement these policies. Revisiting the forest and climate change policies incorporating forestry sector contribution in climate change mitigation and adaptation is essential. Similarly the recognition of local knowledge and community involvement in policy formulation and implementation should be considered.

Dale, V.H., Joyce, L.A., McNulty, S., Neilson, R.P., Ayres, M.P., Flannigan, M.D., Hanson, P.J., Irland, L.C., Lugo, A.E., Peterson, C.J. and Simberloff, D. 2001. Climate Change and Forest Disturbances. BioScience, 51(9): 723-734.

DoF, 2014.Community Forestry Development Guideline (Third Revision, 2014). Department of Forests, Kathamandu, Nepal.

FAO, 2010. Managing Forests for Climate Change. Food and Agricultural Organizations of the United Nations. Accessd on 24th July 2017, from http://www.fao.org/docrep/013/ i1960e/i1960e00.pdf

GoN, 2010. National Adaptation Program of Action, 2010. Ministry of Environment, Science and Technology, Government of Nepal.

GoN, 2011. Climate Change Policy, 2011. Ministry of Environment, Science and Technology, Government of Nepal.

GoN, 2011. Forest Carbon Measurement Guideline, 2011. Ministry of Forests and Soil Conservation, Government of Nepal.

GoN, 2014. Nepal Biodiversity Strategy and Action Plan (2014-2020). Ministry of Forests and Soil Conservation, Government of Nepal. 
GoN, 2015. Forest Policy, 2015. Ministry of Forests and Soil Conservation, Government of Nepal.

GoN, 2016. Forestry Sector Strategy (2016-2025). Ministry of Forests and Soil Conservation, Government of Nepal.

GoN, 2018. Nepal National REDD+ Strategy, 2018. Ministry of Forests and Soil Conservation, Government of Nepal.

HELVETAS and RRI, 2011. Nepal's Climate Change Policies and Plans: Local Communities Perspectives. Environment and climate change series 2011/1. HELVETAS Nepal and Rights and Resources Initiative.

Homer-Dixon, T. 1994. Environmental Scarcities and Violent Conflict: Evidence from Cases. International Security, 19(1): 5-40.

IPCC, 2013. Summary for Policymakers. In: T.F. Stocker, D. Qin, G.-K. Plattner, M. Tignor, S.K. Allen, J. Boschung, A. Nauels, Y. Xia, V. Bex and P.M. Midgley (Eds.), Climate Change 2013: The Physical Science Basis. Contribution of Working Group I to the Fifth Assessment Report of the Intergovernmental Panel on Climate Change Cambridge University Press, Cambridge, United Kingdom and New York, NY, USA.

IPCC, 2014. Summary for Policymakers. In: O. Edenhofer, R. Pichs-Madruga, Y. Sokona, E. Farahani, S. Kadner, K. Seyboth, A. Adler, I. Baum, S. Brunner, P. Eickemeier, B. Kriemann, J. Savolainen, S. Schlömer, C. von Stechow, T. Zwickel and J.C. Minx (eds.), Climate Change 2014: Mitigation of Climate Change. Contribution of Working Group III to the Fifth Assessment Report of the Intergovernmental Panel on Climate Change Cambridge University Press, Cambridge, United Kingdom and New York, NY, USA.
Joshi, P.K., Rawat, A., Narula, S. and Sinha, V. 2012. Assessing Impact of Climate Change on Forest Cover Type Shifts in Western Himalayan Eco-region. Journal of Forestry Research, 23(1): 75-80.

Larson, A.M. 2011. Forest Tenure Reform in the Age of Climate Change: Lessons for REDD+. Global Environmental Change, 21(2): 540-549.

McCarty, J.P. 2001. Ecological Consequences of Recent Climate Change. Conservation Biology, 15(2): 320-331.

MoPE, 2017a. Synthesis of Stocktaking Report for National Adaptation Plan (NAP) Formulation Process in Nepal. Ministry of Population and Environment, Kathmandu.

MoPE, 2017b. Vulnerability and Risk Assessment Framework and Indicators for National Adaptation Plan (NAP) Formulation Process in Nepal. Ministry of Population and Environment (MoPE), Kathmandu.

MSFP, 2015. Local Adaptation Planning in Forestry Sector; Process Guide Book. Multistakeholder Forestry Programme.

Obioha, E. E. 2008. Climate Change, Population Drift and Violent Conflict Over Land Resources in Northeastern Nigeria. Journal of Human Ecology, 23(4): 311-324.

Ojha, H. R., Ghimire, S., Pain, A., Nightingale, A., Khatri, D. B. and Dhungana, H. 2016. Policy Without Politics: Technocratic Control of Climate Change Adaptation Policy Making in Nepal. Climate Policy, 16(4): 415-433.

Ojha, H., Timsina, N. and Khanal, D. 2007. How are Forest Policy Decisions Made in Nepal. Journal of Forest and Livelihood, 6(1): 1-16. 
Parmesan, C. and Yohe, G. 2003. A Globally Coherent Fingerprint of Climate Change Impacts Across Natural Systems. Nature, 421(6918):37-42.

Paudel, G. 2014. Analysis of Equity, Poverty and Sustainability Aspects of Community Forests of Nepal. VIKAS (A Journal of Development), 36(1): 89-96.

Paudel, G. 2015. Forest Resource Income Variation in Mid-hills of Nepal: A Case Study from Two CFUGs of Parbat district, Nepal. International Journal of Environment, 4(3): 1-10.

Pramova, E., Di Gregorio, M., and Locatelli, B. 2015. Integrating Adaptation and Mitigation in Climate Change and Landuse Policies in Peru. Working Paper 184. Bogor, Indonesia: CIFOR, 1-19.

RECOFTC, 2012. Forests and Climate Change Adaptation in Asia. Accessed 05 Septmeber 2017 at https://www.recoftc.org/recoftc/ download/4594/815

Regmi, B.R. and Karki, G. 2010. Local Adaptation Plans in Nepal. Tiempo, 21-25.

Shrestha, H.P. and Shrestha, P. 2012. Tourism in Nepal: A Historical Perspective and Present Trend of Development. Himalayan Journal of Sociology and Anthropology, 5: 54-75.

Smith P., Bustamante, M., Ahammad, H., Clark, H., Dong, H., Elsiddig, E.A., Haberl, H., Harper, R., House, J., Jafari, M., Masera, O., Mbow, C., Ravindranath, N. H., Rice, C. W., Robledo A. C., Romanovskaya, A., Sperling, F. and Tubiello, F. 2014: Agriculture, Forestry and Other Land Use (AFOLU). In: O. Edenhofer, R. PichsMadruga, Y. Sokona, E. Farahani, S. Kadner, K. Seyboth, A. Adler, I. Baum, S. Brunner, P. Eickemeier, B. Kriemann, J. Savolainen, S. Schlömer, C. von Stechow,
T. Zwickel and J.C. Minx (Eds.), Climate Change 2014: Mitigation of Climate Change. Contribution of Working Group III to the Fifth Assessment Report of the Intergovernmental Panel on Climate Change. Cambridge University Press, Cambridge, United Kingdom and New York, NY, USA.

Spittlehouse, D.L. and Stewart, R.B. 2004. Adaptation to Climate Change in Forest Management. Journal of Ecosystems and Management, 4(1): 1-11.

Stern, N.H. 2007. The Economics of Climate Change: The Stern review. Cambridge University press.

Streck, C. and Scholz, S.M. 2006. The Role of Forests in Global Climate Change: Whence we Come and Where we Go. International Affairs, 82(5): 861-879.

Tripathi, S., Thapa, C.B., Sharma, A. and Paudel, G. 2017. Biomass Carbon Content in SchimaCastanopsis Forest of Midhills of Nepal: A Case Study from Jaisikuna Community Forest, Kaski. International Journal of Environment, 6(4): 72-83.

Thuy, P.T., Moeliono, M., Locatelli, B., Brockhaus, M., Gregorio, M.D. and Mardiah, S. 2014. Integration of Adaptation and Mitigation in Climate Change and Forest Policies in Indonesia and Vietnam. Forests, 5(8): 2016-2036.

Walther, G.R., Post, E., Convey, P., Menzel, A., Parmesan, C., Beebee, T.J., Fromentin, J.M., Hoegh-Guldberg, O. and Bairlein, F. 2002. Ecological Responses to Recent Climate Change. Nature, 416(6879): 389395. 